\title{
Rancang Bangun Sistem Ketertelusuran Rantai Pasok Ayam Pedaging Melalui Aplikasi Android Berbasis Blockchain
}

\section{The Design of Broiler Supply Chain Traceability System through Blockchain-Based Android Applications}

\author{
MEIDHIANTO USMAN ${ }^{1}$, IRMAN HERMADI $^{1 *}$, YANDRA ARKEMAN $^{2 *}$
}

\begin{abstract}
Abstrak
Sistem manajemen rantai pasok di agroindustri sejak tahun 2000-an telah menjadi sistem manajemen rantai pasok yang terpusat. Sistem seperti itu memiliki kelemahan seperti masalah korupsi, keamanan, dan sistem informasi yang tidak tepat, membuat sistem rantai pasokan tidak berjalan sesuai rencana. Blockchain merupakan salah satu hasil teknologi di era 4.0 ini. Teknologi blockchain dapat diartikan sebagai buku besar terdistribusi yang melacak setiap aktivitas dalam rantai blok yang merupakan aktivitas yang telah dilakukan. Penerapan teknologi blockchain dapat memberikan keuntungan bagi semua pelaku rantai pasok, mulai dari produsen kecil, pengolah, distributor hingga konsumen. Teknologi blockchain membantu meningkatkan efisiensi rantai pasokan dengan menyediakan sistem pelacakan untuk semua peristiwa yang terjadi dalam rantai pasokan dan kualitas produk. Tujuan dari penelitian ini adalah untuk merancang sistem ketertelusuran rantai pasok ayam pedaging. Metode dalam penelitian ini menggunakan metode prototyping. Hasil dari penelitian ini adalah aplikasi Android berbasis blockchain untuk sistem ketertelusuran rantai pasok ayam pedaging.
\end{abstract}

Kata kunci: android, blockchain, broiler, ketertelusuran, rantai pasok

\begin{abstract}
The supply chain management system in agro-industry since the 2000s has been a centralized supply chain management system. Such a system has weaknesses such as problems with corruption, improper security and information systems, making the supply chain system not run as planned. Blockchain is one of the technological results in this 4.0 era, where blockchain technology can be interpreted as a distributed ledger that tracks every activity in the blockchain, where every record of the activity is an activity that has been carried out. Using blockchain technology can provide benefits for all supply chain actors, from small producers, processors, distributors to consumers. Blockchain technology helps improve supply chain efficiency by providing a tracking system for all events occurring in the supply chain and product quality. The purpose of this research is to design a traceability system for the broiler supply chain. The method in this research is the prototyping method. The result of this study is blockchain-based on Android application for the broiler supply chain traceability system.
\end{abstract}

Keywords: android, blockchain, broilers, supply chain, traceability

\section{PENDAHULUAN}

Mayoritas masyarakat Indonesia mengonsumsi daging ayam sebagai salah satu sumber protein hewani yang dibutuhkan oleh tubuh manusia. Makan daging ayam sangat digemari oleh masyarakat. Menurut data BPS (2015) tingkat konsumsi masyarakat Indonesia akan daging ayam menempati urutan pertama terbesar di atas tingkat konsumsi daging sapi. Ayam pedaging atau yang lebih dikenal dalam masyarakat dengan sebutan ayam broiler, saat ini telah banyak

\footnotetext{
${ }^{1}$ Departemen Ilmu Komputer, FMIPA, IPB University

2*Penulis Korespondensi: Tel/Faks: 0251-8625584; Surel: irmanhermadi@apps.ipb.ac.id

Departemen Teknologi Industri Pertanian, FATETA, IPB University

*Penulis Korespondensi: Tel/Faks: 0251-8625584; Surel: yandra@apps.ipb.ac.id
} 
diusahakan dan dikembangkan, baik oleh pengusaha-pengusaha besar daerah perkotaan maupun pengusaha-pengusaha kecil yang berada di pedesaan. Seiring dengan naiknya permintaan ayam pedaging setiap tahunnya, perlu dirancang sebuah sistem ketertelusuran rantai pasok ayam pedaging. Rantai pasok adalah semua kegiatan atau usaha yang melibatkan semua pihak yang memproduksi dan atau menghasilkan barang dan jasa, mulai dari produsen dan atau supplier bahan baku sampai pada konsumen akhir (Lokollo 2012). Manajemen rantai pasokan adalah sebuah sistem yang melibatkan proses produksi, pengiriman, penyimpanan, distribusi dan penjualan produk untuk memenuhi permintaan akan produk tersebut, termasuk seluruh proses dan kegiatan yang terlibat di dalam penyampaian produk tersebut sampai ke tangan konsumen (Wuwung 2013). Sistem manajemen rantai pasok pada agroindustri sejak tahun 2000-an merupakan sistem manajemen rantai pasok yang tersentral. Sistem seperti ini memiliki kelemahan di antaranya masih memiliki otoritas terpusat sehingga dapat menyebabkan masalah korupsi, keamanan sistem dan informasi yang tidak semestinya sehingga membuat sistem rantai pasok tidak berjalan sesuai dengan apa yang telah direncanakan. Kelemahan lainnya adalah data yang tidak disajikan secara real-time dan transparan serta membutuhkan waktu dalam pengolahan dan penyajian. Untuk mengatasi masalah ini, alternatif baru yang kini bisa digunakan adalah teknologi blockchain.

Blockhain adalah salah satu hasil teknologi pada era 4.0 ini yang dapat didefinisikan sebagai buku besar terdistribusi yang melacak setiap aktivitas dalam rantai blok, yang mana setiap catatan aktivitas tersebut adalah aktivitas yang telah divalidasi (Bogart and Rice 2015). Setiap blok dalam blockchain berisi data dari semua transaksi di dalam sistem selama jangka waktu tertentu serta dapat membuat sebuah tanda tangan digital yang dapat digunakan untuk memverifikasi validitas informasi yang berhubungan dengan blok berikutnya dan sebelumnya Bruce (2013). Transaksi yang telah dilakukan akan disimpan dalam blok hash. Apabila transaksi tersebut sudah terverifikasi dengan sebuah konsensus dari seluruh atau mayoritas anggota dalam jaringan, transaksi yang telah disimpan dalam blok tidak dapat diubah atau dihapus. Hyperledger fabric adalah salah satu framework untuk mengembangkan sistem atau aplikasi berbasis blockchain. Scherer (2017) menyatakan bahwa hyperledger fabric lebih cepat dan mudah dikembangkan dibandingkan Bitcoin dan Ethereum, dan dapat memastikan akses data dalam sistem hanya dapat diakses oleh peserta yang terlibat di dalam jaringan sehingga peserta dapat melihat detail dari transaksi yang dilakukan.

Beberapa penelitian terdahulu telah dilakukan dalam pembuatan sistem berbasis blockchain untuk rantai pasok. Tian (2016) telah membangun sebuah sistem terdistribusi yang terdesentralisasi untuk melakukan penelusuran rantai pasok pangan hasil pertanian di China yang berbasis blockchain dan radio-frequency identification (RFID) yang mencakup keseluruhan proses pengumpulan data dan manajemen pengawasan, ketertelusuran kualitas serta keamanan pangan hasil pertanian. Hal itu bergantung pada BigchainDB untuk menyimpan dan mengelola data produk yang relevan dalam rantai pasok. Anggota-anggota yang termasuk dalam rantai pasokan seperti pemasok, para produsen, distributor, pengecer, konsumen dan pemberi sertifikat dapat menambah, memperbaharui dan memeriksa informasi tentang produk di BigchainDB selama mereka mendaftar sebagai pengguna dalam sistem.

Penelitian tesis yang dilakukan Dwi (2019) tentang perancangan dan implementasi teknologi blockchain pada sistem pencatatan hasil rekapitulasi pemilu berdasarkan formulir $\mathrm{C} 1$ pindaian KPU menghasilkan sebuah sistem teknologi berbasis blockchain yang dapat mendukung sistem pencatatan hasil pemilu secara real count dengan basis data terdistribusi yang aman dari serangan para peretas. Sistem yang dibangun juga sebagai media informasi yang transparan serta dapat mendeteksi adanya manipulasi data hasil perhitungan suara oleh KPU. Teknologi blockchain memiliki konsep penyimpanan data yang tersebar (decentralized) sehingga semua anggota dalam sebuah organisasi akan mendapatkan salinan transaksi yang dilakukan oleh tiap anggotanya. Salinan transaksi yang dimiliki saling terkait satu sama lain atau saling terkait dengan transaksi sebelumnya dan tersimpan dalam sebuah blok hash yang 
menggunakan algoritme kriptografi Secure Hash Algorithm (SHA) 256 sehingga transaksi mejadi lebih aman dan terpercaya.

Metode yang digunakan dalam penelitian ini adalah metode prototyping. Penelitian ini memanfaatkan rancang bangun sistem ketertelusuran rantai pasok ayam pedaging melalui aplikasi Android berbasis blockchain yang dapat mencatat transaksi dan informasi para aktor yang terlibat didalam rantai pasok serta dapat melakukan ketertelusuran rantai pasok ayam pedaging secara real-time dan transparan dengan menggunakan BatchID yang berasal dari para aktor sehingga dapat menimbulkan kepercayaan para pemakai. Dengan menggunakan teknologi blockchain dapat memberikan manfaat bagi semua pelaku rantai pasok mulai dari hulu hingga hilir.

\section{METODE}

\section{Data Penelitian}

Data yang diperlukan dalam penelitian ini adalah data primer dan data sekunder. Data primer dikumpulkan melalui wawancara dan observasi. Wawancara dilakukan pada stakeholder yang terlibat dalam rantai pasok untuk memperoleh informasi yang tepat dan lebih mendalam berkaitan dengan data produksi, harga jual, dan pesanan ayam pedaging. Data sekunder dikumpulkan melalui studi literatur seperti jurnal, artikel, maupun dari internet selama proses penyusunan penelitian.

\section{Tahapan Penelitian}

Tahapan dalam penelitian ini menggunakan metode prototyping yang terdiri dari lima tahapan yaitu: communication, quick plan, modeling quick design, construction of prototype dan deployment, delivery and feedback seperti yang ditunjukan pada Gambar 1.

\section{HASIL DAN PEMBAHASAN}

Pada bab ini akan menjelaskan iterasi awal hasil dan pembahasan dari rancangan penelitian terkait dengan rancang bangun sistem ketertelusuran rantai pasok ayam pedaging melalui aplikasi Android berbasis blockchain pada PT XYZ.

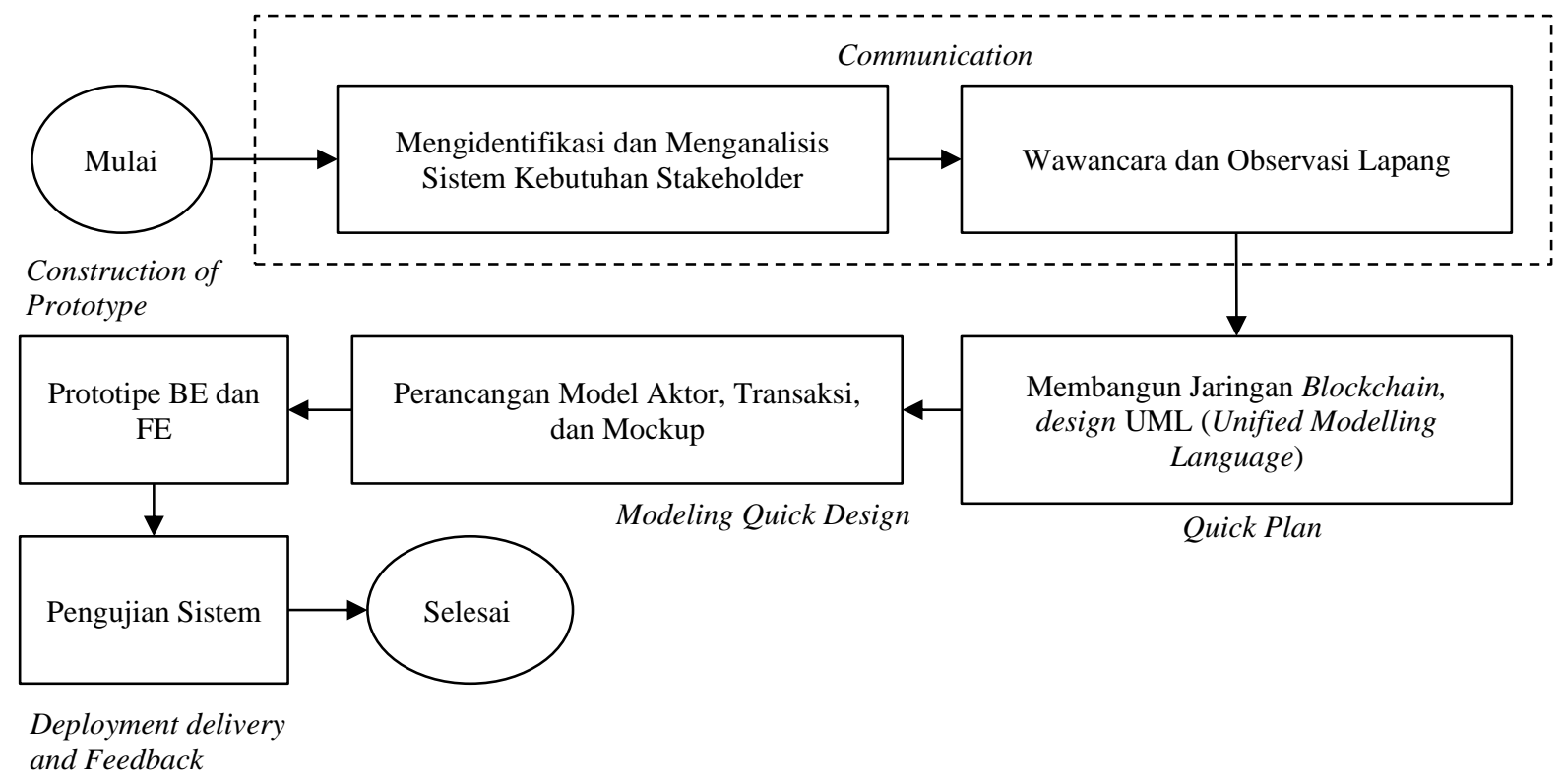

Gambar 1 Tahapan penelitian. 


\section{Communication}

Dalam tahap ini dilakukan identifikasi dan menganalisis kebutuhan stakeholder dan sistem secara keseluruhan sebagai kebutuhan dan acuan dalam pembuatan perangkat lunak. Kebutuhan yang dianalisis berupa kebutuhan data, informasi, aturan dan prosedur serta proses bisnis para aktor yang terlibat didalam rantai pasok didapatkan dari hasil wawancara dan observasi langsung pada PT XYZ sehingga pada tahap ini diperoleh model sistem ketertelusuran rantai pasok ayam pedaging berbasis teknologi blockchain yang terdiri atas lima aktor yaitu: peternak, perusahaan, pengepul, pengecer dan konsumen.

Alur sistem transaksi rantai pasok yang berisikan tiga fungsi utama dalam sistem blockchain: melakukan, konfirmasi, dan melihat transaksi (Gambar 2). Aliran transaksi yang terjadi berawal dari peternak yang melakukan transaksi kepada perusahaan, kemudian perusahaan akan melakukan update transaksi untuk diteruskan kepada pengepul dan hal yang sama dilakukan pengepul ketika akan bertransaksi dengan pengecer. Meskipun terpisah, transaksi ayam tersebut bila ditelusuri akan memiliki asal ayam yang dijual oleh peternak yang sama. Setiap entitas yang terlibat dalam rantai pasok berkolerasi dengan jaringan blockchain.

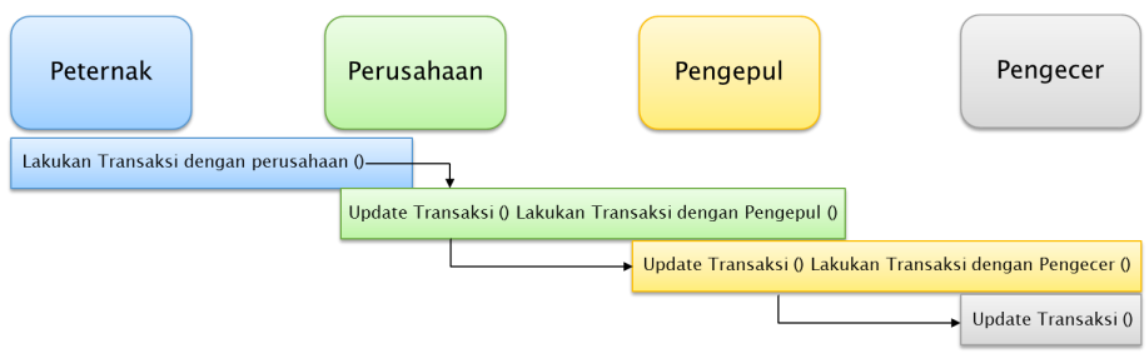

Gambar 2 Alur transaksi antar-aktor.

\section{Quick Plan}

Pada tahap ini dihasilkan data user requirement sesuai dengan analisis kebutuhan user dalam pembuatan perangkat lunak termasuk rencana perancangan proses bisnis, pembuatan use case, activity dan class diagram serta struktur dari jaringan blockchain untuk menganalisis aliran kerja sistem yang dikembangkan. Berdasarkan hasil wawancara, dilakukan analisis terhadap proses bisnis yang berjalan pada perusahaan sehingga diputuskan proses bisnis yang akan dirancang untuk penelitian ini hanya berfokus pada informasi dan transaksi permintaan serta distribusi ayam pedaging saja. Proses bisnis yang dirancang untuk rantai pasok ayam pedaging ini terdapat pool peternak hanya mencakup pemenuhan permintaan dan pembelian ayam oleh perusahaan, pool perusahaan yang terdiri dari tiga pool untuk pembelian dan permintaan ayam, penyimpanan ayam, serta proses produksi dalam hal ini pengiriman ayam, pool distributor yaitu pengepul dan pengecer yang akan mendistribusikan ayam, dan pool konsumen sebagai pembeli ayam dari pengecer dan pengkonsumsi ayam. Gambar 3 menunjukkan proses bisnis yang telah dijelaskan.

Diagram use case merupakan bagian tertinggi dari fungsionalitas yang dimiliki sistem yang akan menggambarkan bagaimana seseorang atau aktor akan menggunakan dan memanfaatkan system. Diagram use case (Gambar 4) menunjukkan interaksi antara aktor dan aplikasi, yaitu peternak, perusahaan, pengepul, pengecer. Konsumen merupakan user yang dapat melacak ketertelusuran dan ada seorang admin yang dapat mengakses basis data. Terdapat beberapa fungsi yang dirancang pada aplikasi Android berbasis teknologi blockchain ini (Tabel 1).

Activity diagram yang dirancang pada tahap ini (Gambar 5) berfungsi untuk mendeskripsikan suatu alur proses aktivitas yang terjadi mulai dari awal sampai akhir. Aktivitas yang dilakukan oleh setiap aktor pada rantai pasok ayam pedaging ini pada dasarnya sama, dimulai dengan aktor melakukan registrasi dan mengisi kelengkapan data, kemudian aktor peternak akan melakukan transaksi awal penjualan ayam ke aktor perusahaan. Setelah aktor peternak selesai melakukan transaksi awal, akan dihasilkan sebuah BatchID yang akan digunakan oleh aktor selanjutnya untuk dapat melakukan transaksi serta melakukan konfirmasi 
transaksi penjualan tersebut. BatchID yang dihasilkan dari transaksi awal itulah yang akan digunakan oleh semua aktor hingga sampai pada rantai yang terakhir.

Kelas diagram ini merupakan sebuah fungsi transaksi dan menyimpan semua detail data transaksi. Kelas diagram sistem pada Gambar 6 menunjukkan hubungan informasi dan aktivitas setiap aktor, serta transaksi yang terjadi antar sesama aktor seperti transaksi antara peternak dan perusahaan, perusahaan dan pengepul serta pengepul dan pengecer.

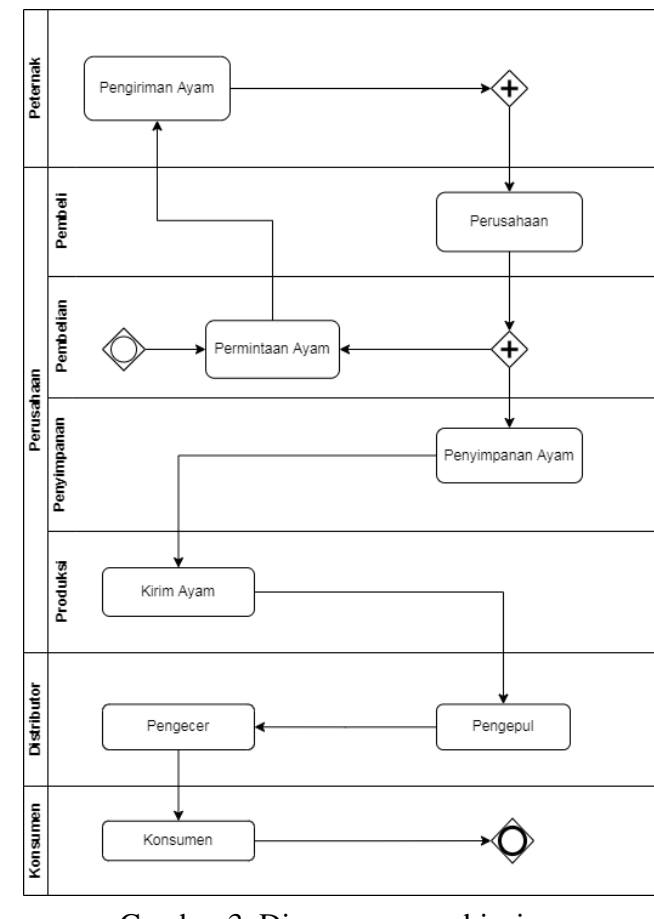

Gambar 3 Diagram proses bisnis.

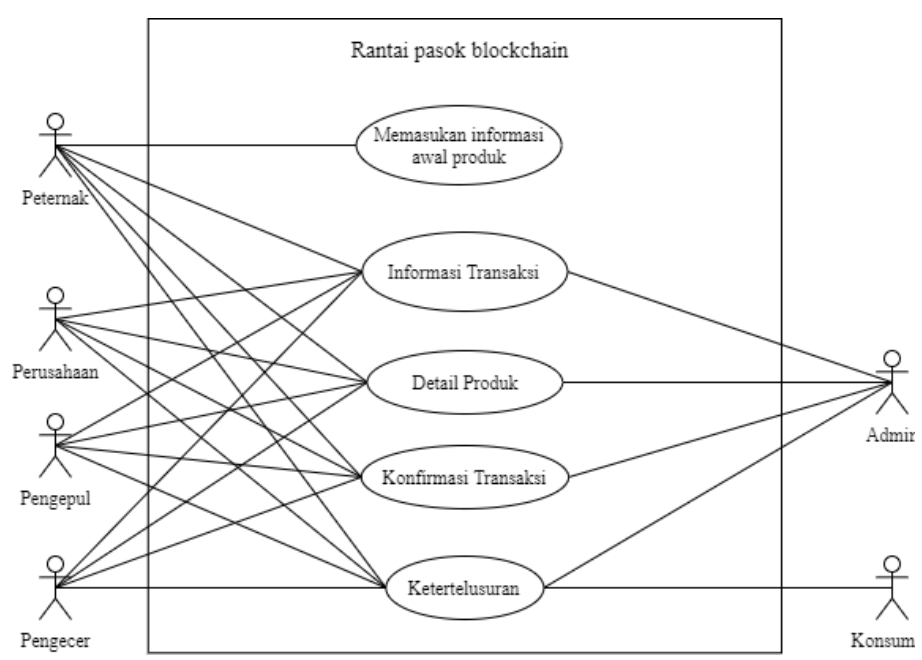

Gambar 4 Diagram use case.

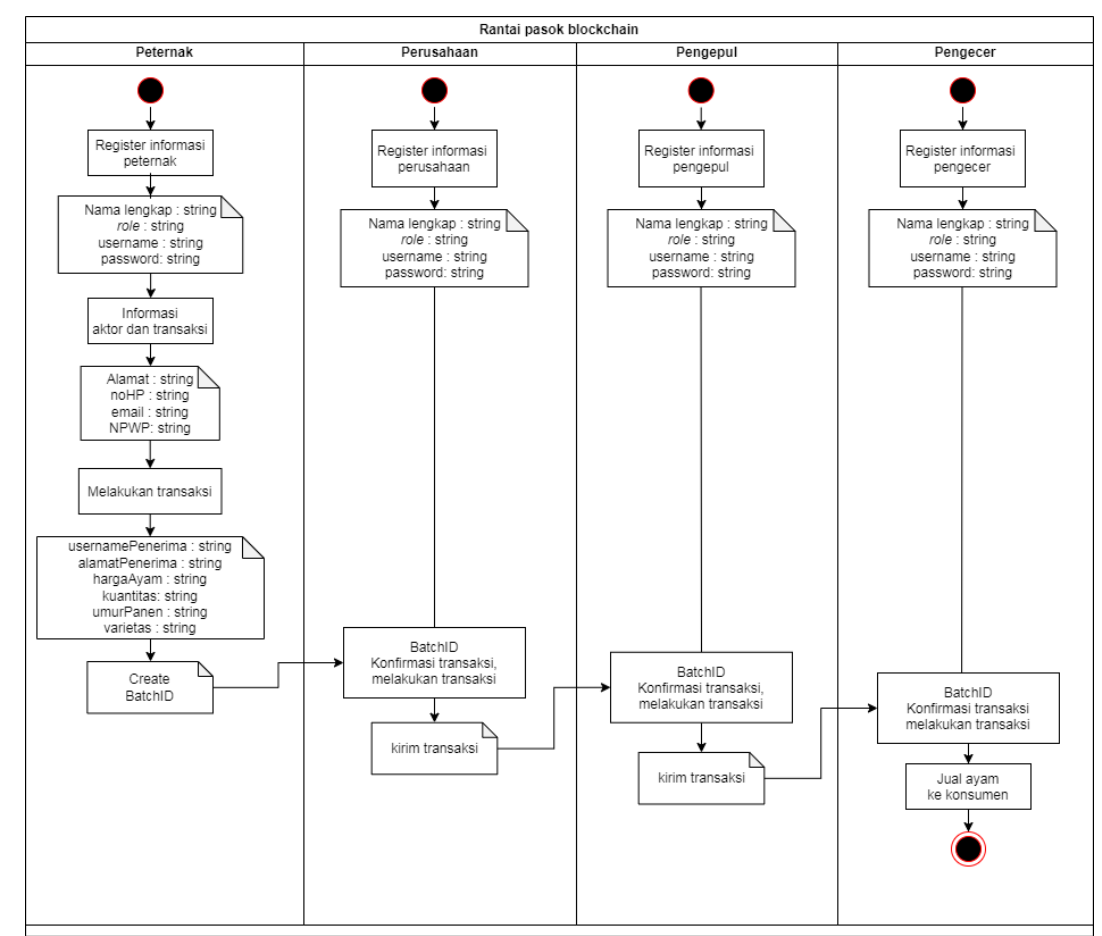

Gambar 5 Activity diagram

Berdasarkan dokumentasi pembuatan jaringan IBM Blockchain Platform pada pranala cloud.ibm.com maka pada Gambar 7 diilustrasikan struktur dari jaringan blockchain yang dibangun dengan menggunakan IBM Blockchain Platform. Struktur jaringan blockchain ini mencakup pembuatan channel dengan organisasi rekan tunggal (single peer organization) 
Tabel 1 Deskripsi use case

\begin{tabular}{|c|c|}
\hline Use case & Deskripsi \\
\hline 1. $\quad$ Login & $\begin{array}{l}\text { Proses masuk kedalam aplikasi dengan menggunakan username dan } \\
\text { password. }\end{array}$ \\
\hline 2. Registrasi & $\begin{array}{l}\text { Merupakan proses pendaftaran setiap pengguna ke dalam aplikasi } \\
\text { agar dapat menjalankan fungsi aplikasi. }\end{array}$ \\
\hline $\begin{array}{l}\text { 3. Create, Read dan Update } \\
\text { transaksi }\end{array}$ & $\begin{array}{l}\text { Fungsionalitas untuk Create, Read dan Update transaksi oleh aktor } \\
\text { dari aplikasi ke database blockchain. }\end{array}$ \\
\hline 4. Konfirmasi transaksi & Otomatisasi transaksi untuk diteruskan kepada aktor lain. \\
\hline 5. Ketertelusuran & Dapat diakses melalui BatchID/QRcode \\
\hline
\end{tabular}

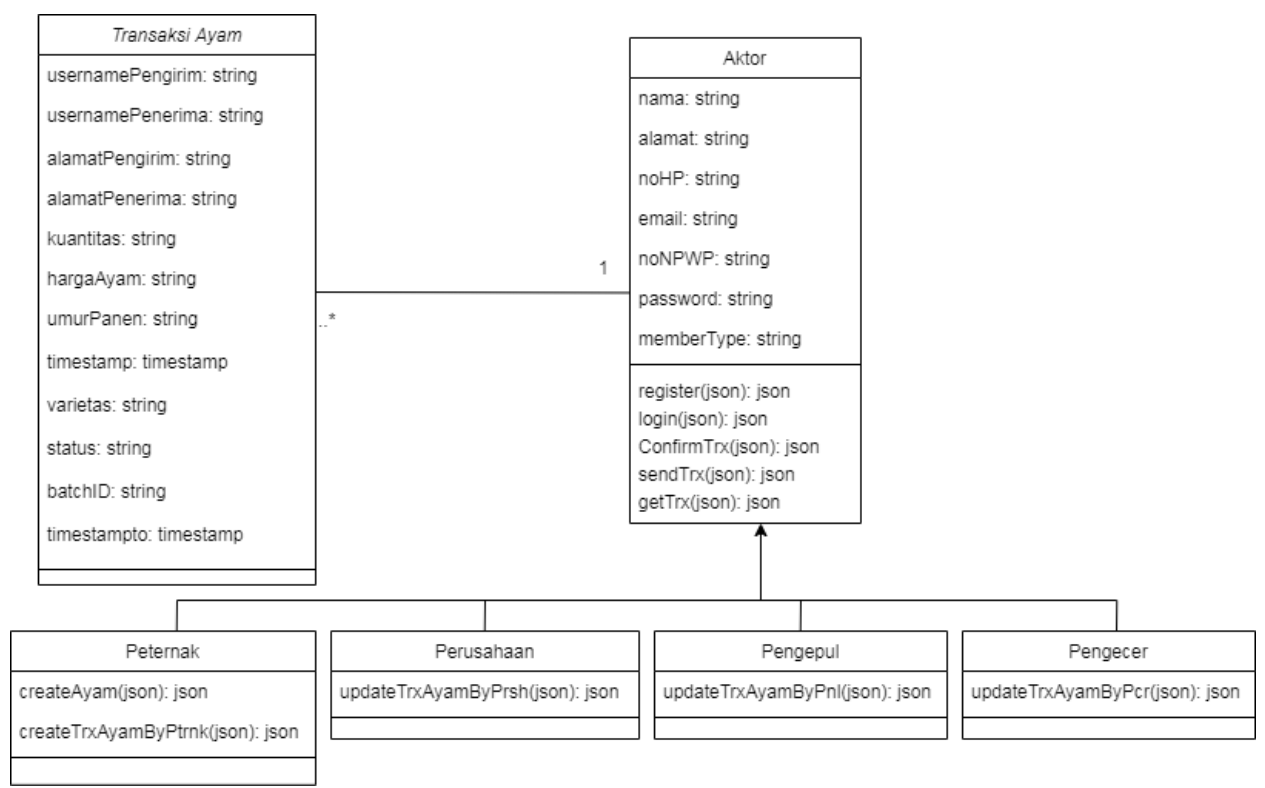

Gambar 6 Class diagram.

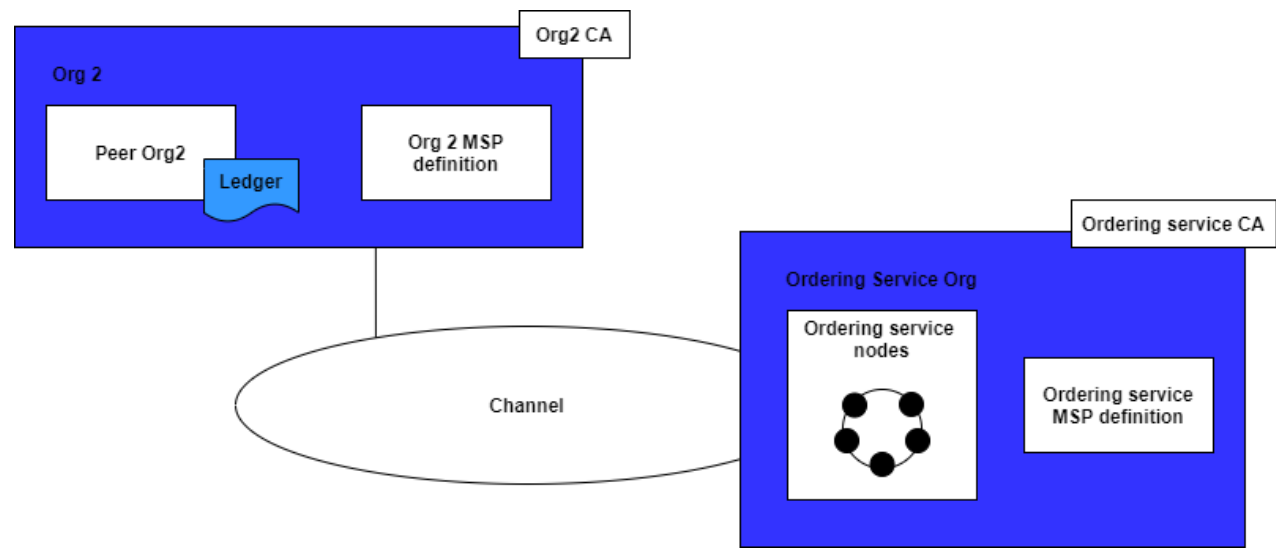

Gambar 7 Struktur jaringan blockchain.

pembuatan membership service provider (MSP) dan certificate authority (CA) sendiri serta organisasi pemesanan (orderer organization) dengan MSP dan CA sendiri. Akan dibuat identitas masing-masing untuk menyebarkan peers dan mengoperasikan nodes.

Alur kerja sistem terbagi menjadi dua bagian yaitu bagian autentikasi pengguna yang terhubung dengan basisdata CouchDB dan blockchain platform itu sendiri. Bagian autentikasi pengguna bertugas untuk menangani login dan register pengguna, sementara bagian blockchain platform bertugas untuk membuat jaringan blockchain serta mengeksekusi fungsi-fungsi dalam smart contract. Kedua bagian tersebut memiliki database dan endpoint API yang sama. Skema alur kerja dari keseluruhan sistem diilustrasikan pada Gambar 8.

Konstruksi arsitektur dari keseluruhan sistem melalui front-end (FE), back-end (BE), dan jaringan blockchain. FE dibangun menggunakan Flutter yang merupakan Software 
Development Kit (SDK) dengan bahasa pemrograman Dart. Flutter adalah teknologi open source dari Google yang bisa digunakan untuk membuat aplikasi Android dan iOS. BE dari sistem informasi dibangun menggunakan ExpressJs sebagai framework NodeJs dengan menggunakan JavaScript serta CouchDB. Menurut Bangare et al. (2016) NodeJs merupakan sebuah platform perangkat lunak yang dapat digunakan untuk membuat server web dan membangun aplikasi web di atasnya. Blockchain platform dibangun menggunakan framework IBM Hyperledger Fabric dan di-deploy pada Kubernetes yang telah disediakan oleh IBM. Kubernetes merupakan platform open source yang digunakan untuk melakukan manajemen workloads aplikasi yang dikontainerisasi, serta menyediakan konfigurasi dan otomatisasi secara deklaratif (Kubernetes 2020). Karena keterbatasan biaya, Kubernetes yang digunakan bersifat free trial. Setelah aplikasi pada BE selesai dibuat dan agar terhubung dengan FE maka aplikasi BE akan di-hosting pada server ilmujaringan.com. Arsitektur aplikasi Android untuk rantai pasok ayam pedaging berbasis teknologi blockchain yang akan digunakan untuk penelitian ini seperti ditunjukan pada Gambar 9.

\section{Modeling Quick Design}

Tahapan ini dilakukan merepresentasikan aspek-aspek dari perangkat lunak (software) yang akan terlihat oleh pengguna akhir (seperti tata letak antarmuka atau format tampilan) (Pressman 2015). Dalam tahapan ini dilakukan perancangan model untuk aktor dan transaksi yang akan disimpan ke dalam blockchain, seperti yang ditunjukan Gambar 10 dan mockup yang diperlukan untuk menjadi dasar pengembangan tata letak antarmuka sesuai dengan kebutuhan ketertelusuran sistem. Perancangan awal melalui home screen application untuk memberikan gambaran atas fungsi-fungsi yang akan diimplementasikan. Perancangan design mockup aplikasi pada platform whimsical.com seperti yang diilustrasikan pada Gambar 11 .

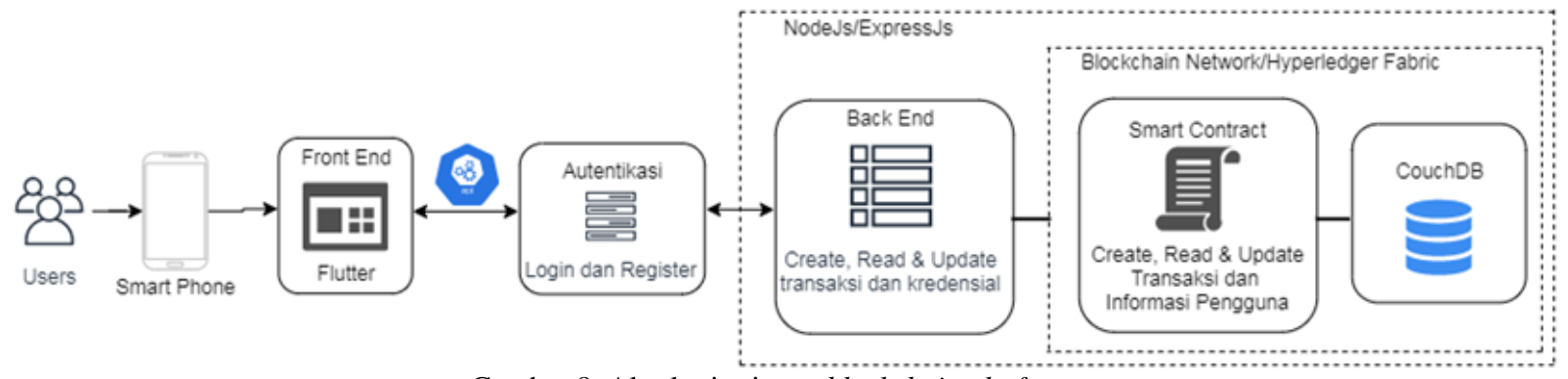

Gambar 8 Alur kerja sistem blockchain platform.

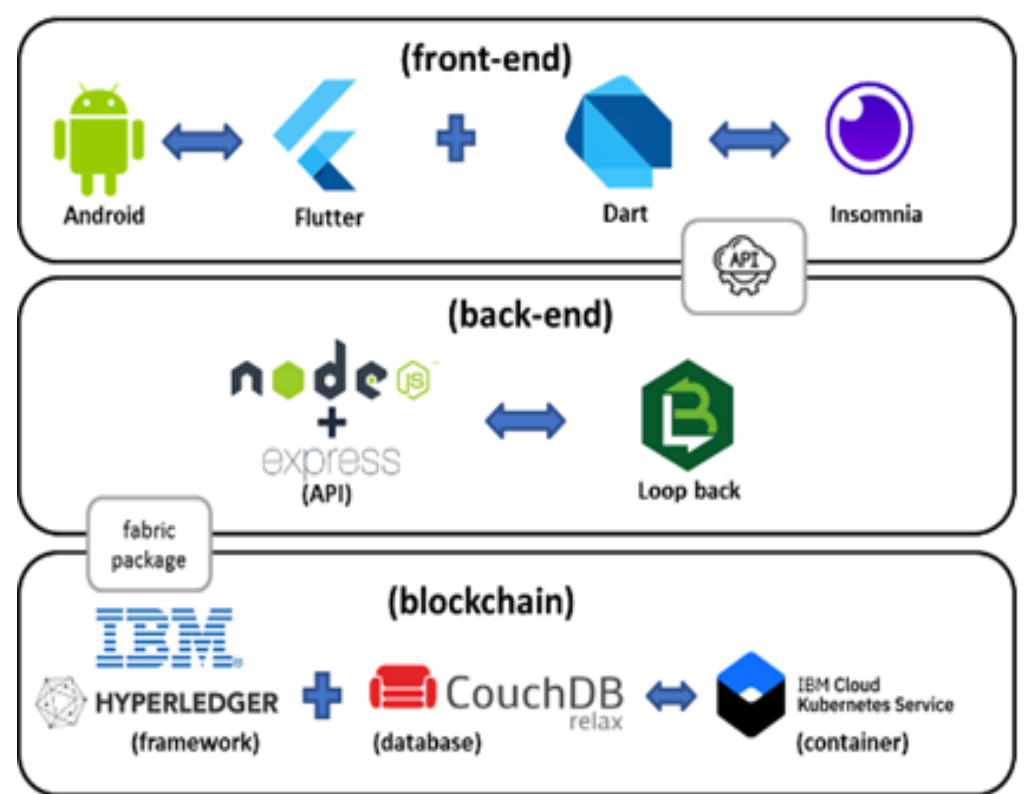

Gambar 9 Arsitektur aplikasi rantai pasok.

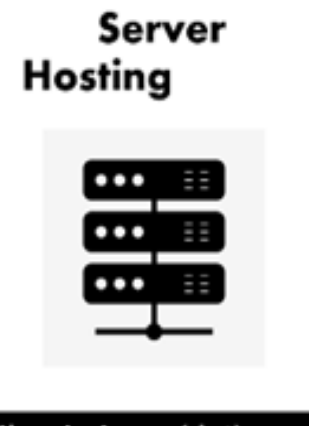

IImujaringan(dot)com

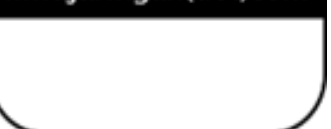



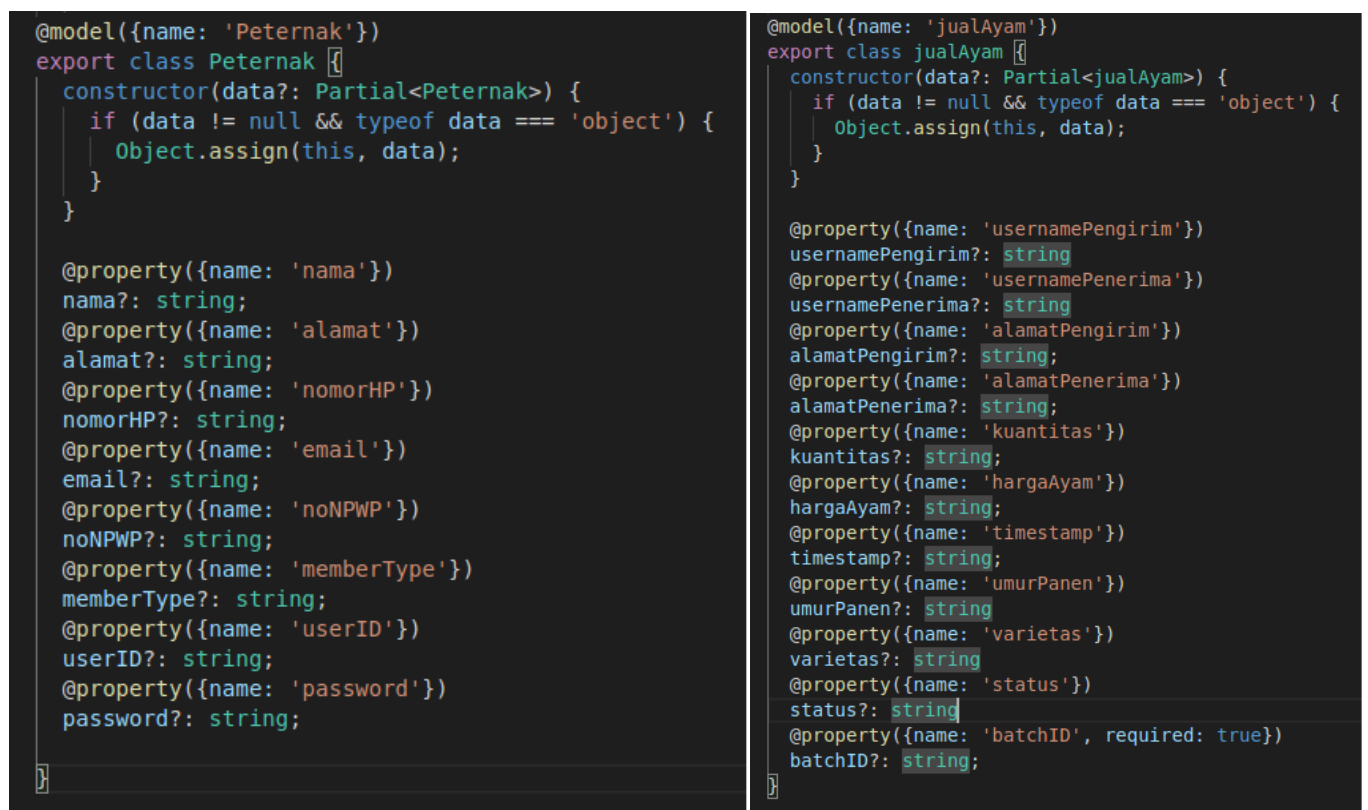

Gambar 10 Model aktor dan transaksi.
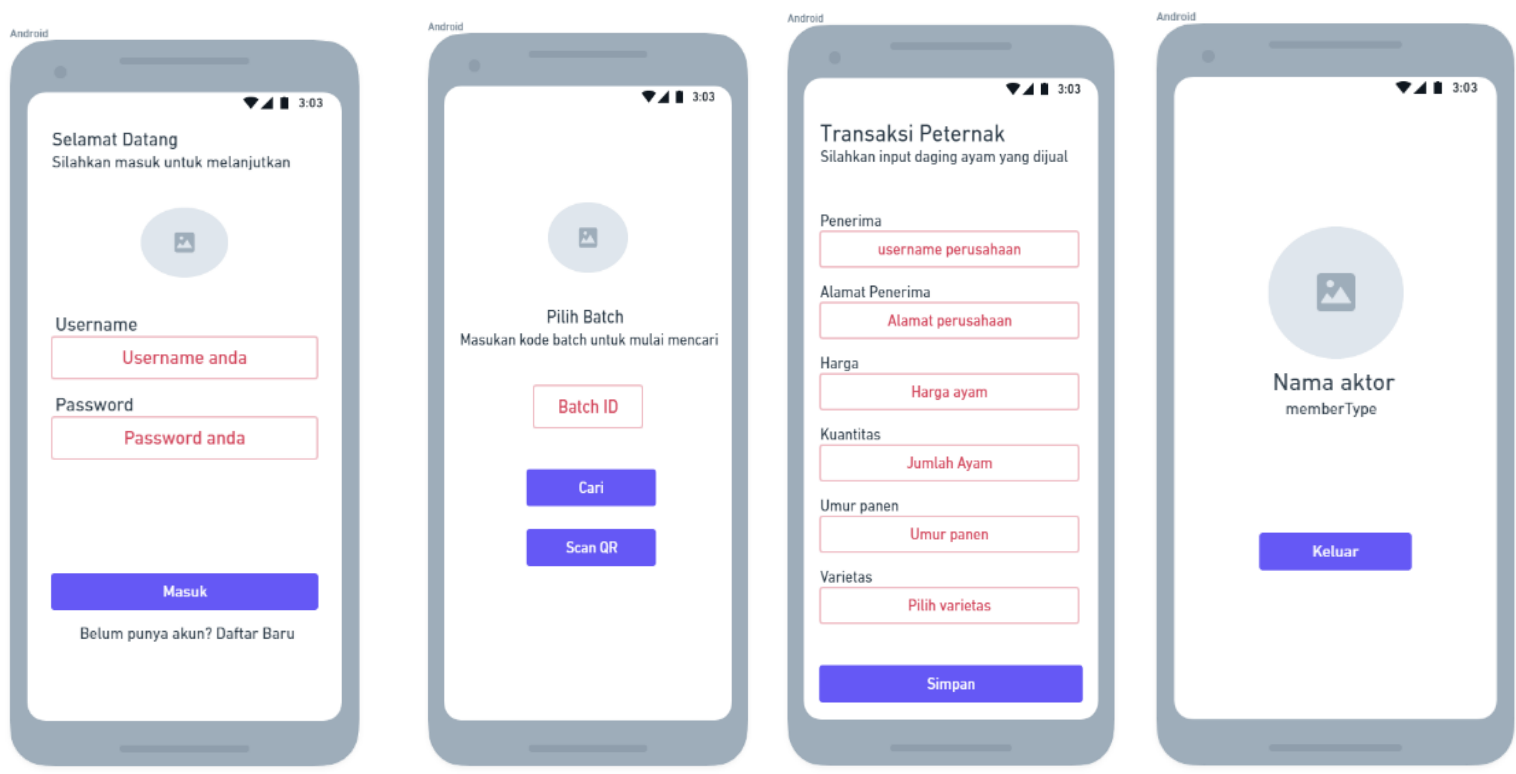

Gambar 11 Mockup aplikasi.

\section{Construction of Prototype}

Berdasarkan perancangan pada tahap sebelumnya bahwa model perancangan untuk aktor dan transaksi pada blockchain dihasilkan konstruksi prototype para aktor dan transaksinya. Sistem ketertelusuran rantai pasok ayam pedaging dapat ditelusuri dengan BatchID sebagai key yang dapat di-generate menjadi QRCode hingga memudahkan para aktor melakukan penelusuran. Hasil scan QRcode yang di-generate dari BatchID untuk ketertelusuran seperti yang ditunjukan pada Gambar 13.

\section{Deployment, Delivery, and Feedback}

Setelah tahapan konstruksi selesai dilakukan sistem back-end blockchain platform dideploy dengan menggunakan server hosting pada ilmujaringan.com. Aplikasi back-end sistem ketertelusuran rantai pasok ayam pedaging ini dapat diakses melalui pranala http://serv.ilmujaringan.com:8080. Pengujian front-end menggunakan metode blackbox testing dengan aplikasi Android dapat diakses melalui aplikasi yang diberi nama "Blockchain Ayam.apk". Untuk menelusuri transaksi mulai dari hulu hingga hilir, BatchID yang digunakan oleh setiap aktor akan menjadi key untuk ketertelusuran rantai pasok ayam pedaging dan dapat 
di generate menjadi QRcode. Komunikasi data antara tampilan aplikasi dan blockchain platform menggunakan API sehingga back-end sudah terintegrasi dengan front end. Pada tahap terakhir ini, prototipe yang telah selesai dibuat diserahkan kepada pengguna untuk melihat apakah sistem ketertelusuran sudah berjalan dengan baik.

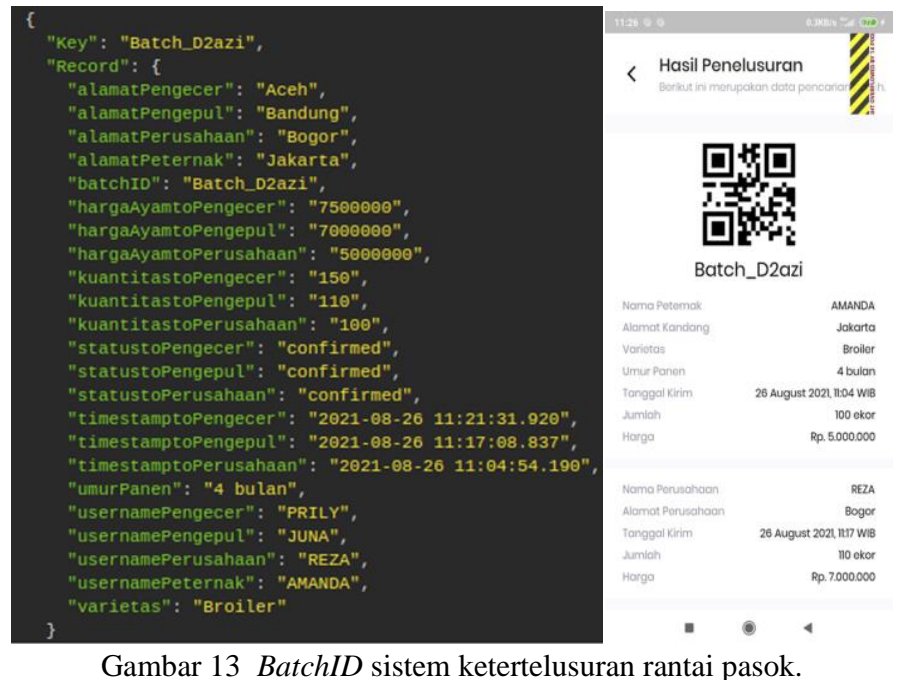

\section{SIMPULAN}

Sistem yang dirancang untuk para aktor mampu menelusuri transaksi rantai pasok ayam pedaging dengan menggunakan BatchID yang dapat di-generate sebagai QRcode, sehingga memudahkan para aktor yaitu peternak, perusahaan, pengepul dan pengecer dalam melacak ketertelusuran rantai pasok ayam pedaging di PT XYZ. Sistem back-end ketertelusuran rantai pasok ayam pedaging menggunakan framework NodeJs dengan bahasa JavaScript untuk bagian autentikasi dan hyperledger fabric sebagai kerangka kerja untuk jaringan IBM Blockchain Platform. Sistem front-end aplikasi Android yang dikembangkan menggunakan Flutter dengan bahasa Dart dan telah mengimplementasikan antarmuka pegguna. Penelitian ini menghasilkan aplikasi Android yang berbasis blockchain sehingga pemanfaatan aplikasi dapat memudahkan, transparansi dan menimbulkan kepercayaan para pemakai.

\section{DAFTAR PUSTAKA}

Bangare SL, Gupta S, Dalal M, Inamdar A. 2016. Using Node. Js to build high speed and scalable backend database server. di dalam: International Journal of Research in Advent Technology Special Issue National Conference "NCPCI-2016". 2016 March 19. [internet] [diunduh 2021 Juni 14]. https://www.researchgate.net/publication/301788361 _Using_NodeJs_to_Build_High_Speed_and_Scalable_Backend_Database_Server.

[BPS] Badan Pusat Statistika. 2015. Distribusi perdagangan komoditas daging ayam ras Indonesia. Katalog BPS: 8201020. ISBN: 978-979-064-893-7.

Bogart S, Kerry R. 2015. The Blockchain Report: Welcome to the Internet of Value. New York (US): Needham \& Company LLC.

Bruce JD. 2013. Purely P2P crypto-currency with finite mini-blockchain. Bitfreak Info [internet]. [diunduh 2020 Nov 17]. citeseerx.ist.psu.edu/viewdoc/ download?doi=10.1.1. 1046.128.

Dwi F H S W. 2019. Perancangan Dan Implementasi Teknologi Blockchain Pada Sistem Pencatatan Hasil Rekapitulasi Pemilu Berdasarkan Formulir C1 Pindaian KPU [tesis]. Institut Teknologi Bandung. Magister Teknik Elektro. 
Kubernetes 2020. kubernetes.io/id/docs/concepts/overview/what-is-kubernetes [diakses 2021 Maret 20].

Lokollo EM. 2012. Bunga Rampai, Rantai Pasok Komoditas Pertanian Indonesia. Lokollo EM, editor. Bogor: IPB Press.

Pressman R.S, Maxim B.R. 2015. Software Engineering: A Practitioner's Approach, Ed ke-8. New York (US): McGraw-Hill.

Scherer M. 2017. Performance and Scalability of Blockchain Networks and Smart Contracts [disertasi]. Swedia: Umeå University in Computing Science and Engineering.

Tian F. 2016. An agri-food supply chain traceability system for China based on RFID \& blockchain technology. Di dalam: 2016 13th International Conference on Service Systems and Service Management (ICSSSM). 2016 Jun 24-26, Kunming, China. hal 1-6

Wuwung SC. 2013. Manajemen Rantai Pasokan Produk Cengkeh Pada Desa Wawona Minahasa Selatan. J EMBA: Jurnal Riset Ekonomi, Manajemen, Bisnis dan Akuntansi, 1(3): 230-238. 